\title{
The Motivation of English Language Teachers in a Language Centre
}

\author{
Chiew Fen $\mathrm{Ng}$ and Poh Kiat $\mathrm{Ng}$
}

\begin{abstract}
A teacher's motivation is basically the character of the teacher's personal enthusiasm and commitment towards teaching and is influenced by the working environment that consist of students, colleagues and managerial staff. Although researchers have argued that the factors that motivate teachers are the same factors that motivate students, the fact that teacher motivation is an area that is frequently overlooked in the domain of second language acquisition still remains. It also appears that few studies that have been done on teacher motivation in the Malaysian context especially in the context of English language centres. Most studies on teacher motivation have been centred in institutional settings, primarily in public schools. Hence, it would be of interest to investigate teacher motivation in a privatised setting such as in an English language centre. This study examines the motivation of language teachers teaching in a language centre in Cheras, Kuala Lumpur. It aims to determine the current degree of motivation among the English language through survey. A review of the literature showed that similar studies from researchers such as Dweik and Awajan (2013) and Yau (2010) have been done on teachers' motivation. Both studies employed quantitative methodologies. Similarly, the current study draws on a quantitative approach in which fifteen 30-item-questionnaires are distributed to the teachers in the English language centre. The findings indicate that the teachers are motivated and strongly motivated because of work autonomy, good work relationships, support from colleagues, superiors and students and also their own intrinsic motivations.
\end{abstract}

Index Terms-English language teacher, language centre, teacher motivation, survey.

\section{INTRODUCTION}

English has become increasingly important as a second language in Malaysia over the years. It is not only used as means for facilitating negotiations for trade and business but more importantly it is also a tool for acquiring knowledge and information. Malaysia is charting a development towards becoming a nation capable of developing and retaining a first-world talent base. In line with this expansion, the Malaysian government intends to improve English proficiency and raise the competitive advantage of Malaysian education through the 10th Malaysian Plan. The government plans to evaluate the effectiveness of different teaching programmes and increase efforts to develop the English proficiency in students [1].

In spite of these efforts, it was found that approximately

Manuscript received April 3, 2015; revised June 23, 2015.

Chiew Fen $\mathrm{Ng}$ is with the Faculty of Modern Language and Communication, Universiti Putra Malaysia, 43400 Serdang, Selangor Darul Ehsan, Malaysia (e-mail: kilaga@gmail.com).

Poh Kiat $\mathrm{Ng}$ is with the Faculty of Engineering and Technology, Multimedia University, Jalan Ayer Keroh Lama, Bukit Beruang, 75450 Malacca, Malaysia (e-mail: pkng@mmu.edu.my).
$40 \%$ of the Malaysian students have an average level of English proficiency [2]. In addition, the new National Education Blueprint (2013-2025) necessitates that immediate and serious attention should be paid to students with low proficiency problems, especially in young learners. In this regard, numerous factors have been recorded for the deteriorating standard of proficiency. The lack of motivation among English language teachers has been attributed as one of the main causes adding to the situation [3].

A number of studies claim that Malaysian students are in general more motivated extrinsically rather than intrinsically [4]. Teachers are a part of this extrinsic aspect of motivation to students. Thus a teachers' motivation can serve as a strong factor in the improvement and development of student achievement, consequently affecting the process of education [5]. Education is a life-long path that continuously shapes and affects behaviour and develops our minds. As the teacher is constantly and continuously a part of this development, it is likely that the formation of desirable behaviour is strongly related to levels of motivation of teachers [5]. Therefore, a teacher with a low level of motivation can affect students' achievement in their learning negatively.

The aforementioned background suggests that teacher motivation can affect student outcomes in education. Although several researchers have argued that the factors that motivate teachers are in fact the same factors that motivate students, the fact that teacher motivation is an area that is frequently overlooked in the domain of second language acquisition still remains. It also appears that there are few studies that have been done on teacher motivation in the Malaysian context especially in the context of English language centres.

Most studies on teacher motivation have been centred in institutional settings, primarily in public schools. Hence, it would be of interest to investigate teacher motivation in a privatised setting such as in an English language centre.

Human behaviour is extremely complex. People can be motivated by various ways and by various means [5]. According to Dweik and Awajan (2013), motivation is not an event that can be observable, nor is it something material which can be scrutinized like an organism or an object. These researchers state that it is only possible to understand motivation through the interpretation of behaviour in individuals and through the conduct of surveys. Thus, the main objective of this research is to determine the current degree of motivation among the English language teachers in an English language learning centre in Cheras, Kuala Lumpur through survey.

Conclusions will be drawn from the data that is analysed and related to previous research findings. The findings from 
this study may offer the management or the employer insights into what motivates an English language teacher, thus facilitating for an improvement in the management system and ultimately creating potential for improving student outcomes. As the study looks into teacher motivation, the contribution of the study would come under the umbrella of second language acquisition.

\section{TEACHERs' Motivation}

Motivation is a force that drives and compels a person to act in the situation to be able to achieve specific goals [6]. It is basically described by Dörnyei (2001) as cited in the works of Praver and Oga-Baldwin (2008) as the thought that is responsible for why people make decisions in carrying out certain actions, the length of time they are prepared to maintain the class activity and how firmly they choose to undertake it. This notion is applicable to language learners and language teachers alike. It is essential that teachers be intrinsically and extrinsically motivated and satisfied so that the level of motivation can be maintained to be able to continue teaching throughout the course of one's teaching career [7]. The mental picture of a teacher who is motivated may be one who is hardworking and strives to try new techniques and activities for the benefit of students ultimately achieving more efficient learning outcomes and satisfaction.

\section{FACTORS ThAT Motivate TEACHERS}

Praver and Oga-Baldwin (2008) did a study to locate a in which a teachers' effectiveness could result from their variety of skills, task significance, task identity, feedback and freedom. Therefore a teacher who has the ability to gain new and diverse professional skills would ultimately have the ability to recognize how teaching is meaningful. He/she would not be impeded to make plans for the best utilisation of his/her skills as an educator, and gather necessary opinion from superiors, co-workers, and students related to the efficacy of his/her techniques.

Thus, there are several factors that can motivate a teacher from the perspective that considers job satisfaction. Praver and Oga-Baldwin (2008) cite from the works of researchers such as Kassabgy, Boraie and Schmidt (2001) the factors that motivate teachers are intrinsic motivation, extrinsic motivation, autonomy, relationship, self realization and institutional support. Thereby, teacher motivation with relevance to job satisfaction is described as:

1) Intrinsic motivation

- is motivation that is driven mainly by internal aspirations to teach

- to establish a relationship through communication between student and teacher

- having a high sense of being efficient in the classroom

- having a high sense of achievement

- the greater the sense of achievement, the higher the student motivation

2) Extrinsic motivation

- controlled by conditions at the workplace, e.g. workload, stress
- appropriate necessities such as proper compensation

- permanence and stability of a long term job

3) Autonomy

- having the freedom to utilise methods, resources and make decisions in the classroom

4) Relationships

- building healthy working relationships to promote a strong work environment

- forming well-built collegiality among co-workers

- maintaining good communication and network within the working environment

5) Self-realisation

- Determining goals which are achievable according to one's personal level

- having a high expectancy of achievement in the classroom

6) Institutional support

- help received from the school

- provide classes for skills for requisite ability

- build expectation of success

- provide proper materials for teaching

- provide proper support and guidance for new teachers

\section{RESEARCH METHODOLOGY}

This study draws on a quantitative approach in which questionnaires are distributed to all the teachers in the particular English language centre. In this study, the survey method is used for data collection. The following section describes in detail the survey method and protocols for this study.

\section{SuRVEy METHOD}

The survey method is the most common of research approaches as compared to other techniques available in social science studies [8]. Its underlying contribution is not mainly in the kind of data it generates, but essentially in its rigorous approach to data collection. The survey method is a type of quantitative research, seeing as it aims to collect data that can be analysed to provide a numerical description of the population's voting intentions [9]. Thus, the survey method is an appropriate approach to be utilised for this study as it entails the development of a questionnaire based on intrinsic and extrinsic motivational elements emerging from the literature review.

\section{DEVELOPMENT OF THE QUESTIONNAIRE}

Based on similar studies by Dweik and Awajan [5], Yau [10] and Praver and Oga-Baldwin [7], a questionnaire which encompasses the elements of intrinsic and extrinsic motivation is developed. Table I presents the items of the modified questionnaire which were based on the preceding articles.

The full questionnaire protocol containing a list of 30 questions can be found in the Appendix. The questionnaire utilises a five point Likert scale, where the respondents are asked to indicate their level of motivation to 30 motivational 
items using a Likert scale of Poorly Motivated $=1$, Slightly Motivated $=2$, Neutral $=3$, Motivated $=4$ and Strongly Motivated $=5$.

TABLE I: QUESTIONNAIRE ITEMS

\begin{tabular}{|c|c|c|}
\hline No & Questionnaire Items & References \\
\hline 1 & I am motivated because I love my job & [5], [7] \\
\hline 2 & $\begin{array}{l}\text { I am motivated because teaching gives security } \\
\text { for my family }\end{array}$ & \\
\hline 3 & $\begin{array}{l}\text { I am motivated because teaching helps me in my } \\
\text { future }\end{array}$ & \\
\hline 4 & $\begin{array}{l}\text { I am motivated because being an English } \\
\text { language teacher is prestigious }\end{array}$ & \\
\hline 5 & I am motivated by my students & \\
\hline 6 & I am motivated by the parents of my students & \\
\hline 7 & $\begin{array}{l}\text { I am motivated by my colleagues and teaching } \\
\text { partners }\end{array}$ & \\
\hline 8 & $\begin{array}{l}\text { I am motivated by my principal/head of } \\
\text { department }\end{array}$ & \\
\hline 9 & $\begin{array}{l}\text { I am motivated by my English language } \\
\text { supervisor }\end{array}$ & \\
\hline 10 & I am motivated by the Ministry of Education & \\
\hline 11 & I am motivated because I earn a good salary & [7], [10] \\
\hline 12 & $\begin{array}{l}\text { I am motivated because I have flexible working } \\
\text { hours }\end{array}$ & \\
\hline 13 & $\begin{array}{l}\text { I am motivated because I have a manageable } \\
\text { work load }\end{array}$ & \\
\hline 14 & $\begin{array}{l}\text { I am motivated because I believe I will be } \\
\text { promoted to a senior supervisory job at some } \\
\text { point in my career }\end{array}$ & \\
\hline 15 & $\begin{array}{l}\text { I am motivated because I have the freedom to do } \\
\text { what is necessary in performing good teaching }\end{array}$ & \\
\hline 16 & $\begin{array}{l}\text { I am motivated because I am clear of the rules } \\
\text { and procedures in my centre/department }\end{array}$ & \\
\hline 17 & $\begin{array}{l}\text { I am motivated because I have the support from } \\
\text { other teachers }\end{array}$ & \\
\hline 18 & $\begin{array}{l}\text { I am motivated because I am able to work } \\
\text { independently and use my own initiative }\end{array}$ & \\
\hline 19 & $\begin{array}{l}\text { I am motivated because I have good } \\
\text { relationships with colleagues }\end{array}$ & \\
\hline 20 & $\begin{array}{l}\text { I am motivated because I have a friendly } \\
\text { relationship with my students }\end{array}$ & \\
\hline 21 & $\begin{array}{l}\text { I am motivated because I have a good } \\
\text { relationship with the person I report to }\end{array}$ & \\
\hline 22 & $\begin{array}{l}\text { I am motivated because I work with colleagues } \\
\text { as a team }\end{array}$ & \\
\hline 23 & $\begin{array}{l}\text { I am motivated because I have a job in which I } \\
\text { can learn and develop my abilities to my full } \\
\text { potential }\end{array}$ & \\
\hline 24 & $\begin{array}{l}\text { I am motivated because I have a job in which I } \\
\text { can perform to the best of my ability }\end{array}$ & \\
\hline 25 & I am motivated because I have a challenging job & \\
\hline 26 & $\begin{array}{l}\text { I am motivated because I am often evaluated } \\
\text { positively by my students }\end{array}$ & \\
\hline 27 & $\begin{array}{l}\text { I am motivated because I am often evaluated } \\
\text { positively by the person I report to }\end{array}$ & \\
\hline 28 & $\begin{array}{l}\text { I am motivated because I am really helping my } \\
\text { students learn English }\end{array}$ & \\
\hline 29 & $\begin{array}{l}\text { I am motivated because I am providing service } \\
\text { to society }\end{array}$ & \\
\hline 30 & $\begin{array}{l}\text { I am motivated because I have a job that is } \\
\text { enjoyable and stimulating }\end{array}$ & \\
\hline
\end{tabular}

\section{PARTICIPANTS}

The surveys are handed out to all the teachers in the particular English language centre. This particular English language centre has been a premier brand in English language education and training for more than 2 decades in Malaysia. The teachers have more than ten years of working experience in teaching English at this centre. In this study, the participants are within the age range of 25 to 45 years. As such, it would be of interest to gather and interpret data concerning the motivation of the English language teachers in this centre to be of reference for other different English language centres across the nation.

\section{SURVEY PROCEDURES}

Due to the limited number of staff in the particular English language centre, only 15 surveys are distributed. The unit of analysis for this study is the English language teachers of the English language centre. The data will be collected and analysed using Microsoft Excel 2007. The analysis of the data will involve the comparison of the mean scores across all the items in the survey. Conclusions will be drawn based on these means and related with previous research findings.

\section{FACE VALIDITY}

Face validity is a measure of how representative a questionnaire is 'at face value,' and whether it appears to be a viable questionnaire (Babbie, 1973). For the face validity, the questionnaire was evaluated by three experienced English language teachers and a lecturer in a university. Based on the face validation in this study, there were no major changes made to the questionnaire.

\section{PILOT STUdY}

Teachers Pilot studies are vital procedures when constructing survey questionnaires (Babbie, 1973). According to Sproull (1995, pp. 349-350), the advantages, are as follows:

- provides information on possible ethical problems;

- provides a check on all aspects of the data collection method;

- provides a check on the validity and reliability of the instruments;

- provides information for modification of all procedures prior to the real test

- enhances the researcher's reputation for thoroughness

A pilot study is therefore necessary for this study. The pilot study is administered after the questionnaire was finalized. The purpose of the pilot study is (1) to field test instrument for practicability, (2) to spot redundant and ambiguous items and (3) to receive feedback from the respondents.

A total of 5 participants completed the pilot study. Based on the responses and feedback received, only certain aspects of the survey such as the layout, formatting and wording of some items were modified. The data collected during the pilot testing stage was discarded and therefore not used for further analyses.

\section{RELIABILITY}

For this study, Cronbach's alpha reliability test was employed. According to Nunnally and Bernstein (1994), Cronbach's alpha is used in this study to evaluate the internal consistency of the survey items. The rule of thumb to measure 
the value is based on an alpha coefficient must be above 0.7 to signify high reliability (Nunnally \& Bernstein, 1994). The current study employed a Cronbach's alpha reliability test and found that the alpha value of all six variables (Intrinsic motivation, Extrinsic motivation, Autonomy, Relationships, Self-realisation and Institutional Support) were well above 0.7 indicating that the internal consistency of the survey data is strong and reliable for further analysis.

\section{RESULTS AND DisCUSSIONS}

The following chart in Fig. 1 represents the results of the data collected from the survey measuring teacher motivation based on factors emerging from the literature review. Based on the percentage of response of teacher motivation, it is found that approximately $50 \%$ of the teachers in this particular English language centre are motivated by all motivation factors (such as Intrinsic, Extrinsic, Autonomy, Relationship and Self-realisation) with the exception of Institutional support, which is only $13.33 \%$. This suggests that the majority of the teachers are lacking institutional support in the language centre environment.

However, teachers still remain motivated by all other factors, mainly autonomy, in which $50 \%$ of the teachers reported as being motivated and $40 \%$ reported as being strongly motivated. Based on these results, autonomy is found to be an important factor in motivating the teachers at the language centre. The results indicate that teachers are strongly motivated when they are granted the freedom to exercise what they deem necessary to be able to teach well and work independently with their own initiative. These findings on autonomy are supported by Ushioda [11] as cited by Praver and Oga-Baldwin (2008) that the more freedom and options an individual is provided, the more likely that the individual will be eager and prepared to work.

Similarly, teachers who have more freedom to form their own goals while teaching have higher tendencies to be motivated in carrying out what they aspire to do in order to achieve the goals they set in the classroom [7]. The results also show that intrinsic motivators such as feeling motivated because there is a sense of providing service to the society keeps $51 \%$ of the language teachers motivated in teaching.

In addition, the teachers are also motivated intrinsically when they gain positive feedback from their students and feel that they are genuinely helping students learn English. It is also found that $60 \%$ of the teachers love their job and $40 \%$ find their job as a language teacher to be enjoyable. This suggests that these teachers are highly motivated due to their inner desire to teach and also by the relationships they forge with their students when communication takes place in class.

It also appears that relationship is the second most important motivating factor in sustaining language teachers' motivation as $52 \%$ of the teachers have reported to be motivated when they establish good relationships with their principal, superior, colleagues and students and receive support and positive evaluation from colleagues and their superiors. This finding is supported by Dwiek and Awajan (2013) who posits that language teachers are generally not motivated when their principals do not provide any morale or emotional support and do not take their views seriously. This ultimately causes teachers to be less motivated which impedes their creativity, efficacy in classroom and sense of responsibility toward their jobs. In order to maintain teachers' motivation, they should be acknowledged emotionally and financially by giving them room for recognition and gratitude as tokens appreciation for their effort and dedication, as well as financial incentives as a fair alternative for acknowledging their performance and hard work [5].

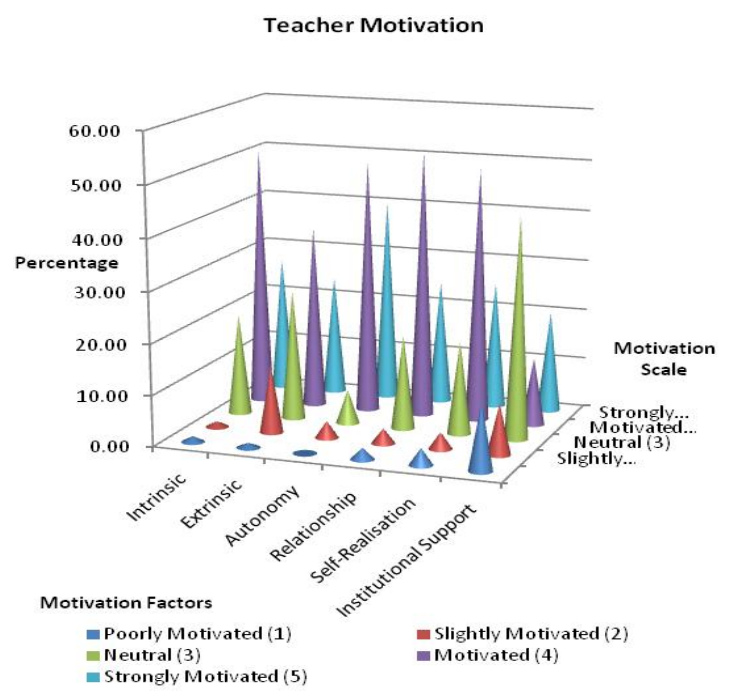

Fig. 1. Survey data results.

On the other hand, the characteristics of the teacher motivation at the centre show that the extrinsic factor is a moderate motivator to teachers as $36 \%$ of the teacher report to be motivated by it. The results revealed that $53 \%$ of the teachers are motivated by the good salary that they are able to earn. However, $66 \%$ of the teachers reported that they are motivated because of the flexible working hours which come with teaching. The findings suggest that their financial issues are the least of their concerns as they would prefer to have more time to carry out their activities of leisure. This could be due to the reason that the teachers have been attached to the language centre for more than 10 years and view themselves as being overcommitted to the language centre.

\section{CONCLUSION}

Based on the data obtained and the results in the previous section, it can be said that the evident findings show that the English language teachers at this particular language centre are motivated and strongly motivated. This is mainly because of the work autonomy that they have at the language centre, the good relationships that they establish at work and the support that they gain from colleagues, superiors and students. Intrinsic motivations in them such as the feeling of contributing to society and finding their job enjoyable and stimulating are also underlying contributing factors.

Overall, the purpose of this study which was to determine the degree of motivation among the English language teachers in an English language learning centre has been fulfilled. The findings of this research potentially presents insights on the motivation of an English language teacher to management or employers, hence allowing for improvement in managerial systems and eventually producing capability for progressing 
student outcomes. Since this research investigates teacher motivation, the potential research contributions would come under the umbrella of second language acquisition.

\section{LIMITATIONS AND FUTURE RESEARCH}

Due to the limitations of availability and time, the sample size of the study was limited to the number of teachers who worked in the language centre. Moreover, the study was limited by the allocation of time provided by the management of the English language centre for the administration of the survey. Suggestions for further research would be to conduct studies with larger data samples or with multiple language centres to enable findings and contributions of the study to be generalized and be applicable in research area of teacher motivation.

Also, the questionnaire could be expanded by adding more motivation factors and items if the language centre allows more time for administration of the questionnaire. As research in teacher motivation have predominantly been conducted in school settings and private settings respectively, it would be of interest to conduct studies in private institutions such as language centres or private schools and public school settings to perform comparative analyses of teacher motivation in both settings for future research.

\section{APPENDIX: QUESTIONNAIRE}

This questionnaire aims to investigate your motivation as an English language teacher in a renowned English language centre. The researchers assure you that the information provided in response to the items in the questionnaire will be used for the sole purposes of academic research. Your cooperation in filling out the questionnaire as accurately as possible is highly appreciated. For further inquiries about this research, please feel free to contact Ms. Justina $\mathrm{Ng}$ via phone number (+606-2523653) or Email (kilaga@gmail.com).

Poorly Motivated: 1, Slightly Motivated: 2, NeUtral: 3, MOTIVATED: 4, STRONGLY MOTIVATED: 5

\begin{tabular}{|c|c|c|c|c|c|c|}
\hline \multirow[t]{2}{*}{ No. } & \multirow[t]{2}{*}{ Questionnaire Items } & \multicolumn{5}{|c|}{$\begin{array}{l}\text { 5-Point Likert } \\
\text { Scale }\end{array}$} \\
\hline & & 1 & 2 & 3 & 4 & 5 \\
\hline 1 & I am motivated because I love my job & & & & & \\
\hline 2 & $\begin{array}{l}\text { I am motivated because teaching gives } \\
\text { security for my family }\end{array}$ & & & & & \\
\hline 3 & $\begin{array}{l}\text { I am motivated because teaching helps me } \\
\text { in my future }\end{array}$ & & & & & \\
\hline 4 & $\begin{array}{l}\text { I am motivated because being an English } \\
\text { language teacher is prestigious }\end{array}$ & & & & & \\
\hline 5 & I am motivated by my students & & & & & \\
\hline 6 & $\begin{array}{l}\text { I am motivated by the parents of my } \\
\text { students }\end{array}$ & & & & & \\
\hline 7 & $\begin{array}{l}\text { I am motivated by my colleagues and } \\
\text { teaching partners }\end{array}$ & & & & & \\
\hline 8 & $\begin{array}{l}\text { I am motivated by my principal/head of } \\
\text { department }\end{array}$ & & & & & \\
\hline 9 & $\begin{array}{l}\text { I am motivated by my English language } \\
\text { supervisor }\end{array}$ & & & & & \\
\hline 10 & $\begin{array}{l}\text { I am motivated by the Ministry of } \\
\text { Education }\end{array}$ & & & & & \\
\hline 11 & $\begin{array}{l}\text { I am motivated because I earn a good } \\
\text { salary }\end{array}$ & & & & & \\
\hline 12 & $\begin{array}{l}\text { I am motivated because I have flexible } \\
\text { working hours }\end{array}$ & & & & & \\
\hline 13 & $\begin{array}{l}\text { I am motivated because I have a } \\
\text { manageable work load }\end{array}$ & & & & & \\
\hline
\end{tabular}

14 I am motivated because I believe I will be promoted to a senior supervisory job at some point in my career

15 I am motivated because I have the freedom to do what is necessary in performing good teaching

16 I am motivated because I am clear of the rules and procedures in my centre/department

17 I am motivated because I have the support from other teachers

18 I am motivated because I am able to work independently and use my own initiative

19 I am motivated because I have good relationships with colleagues

20 I am motivated because I have a friendly relationship with my students

21 I am motivated because I have a good relationship with the person I report to

22 I am motivated because I work with colleagues as a team

23 I am motivated because I have a job in which I can learn and develop my abilities to my full potential

24 I am motivated because I have a job in which I can perform to the best of my ability

25 I am motivated because I have a challenging job

26 I am motivated because I am often evaluated positively by my students

27 I am motivated because I am often evaluated positively by the person I report to

28 I am motivated because I am really helping my students learn English

29 I am motivated because I am providing service to society

30 I am motivated because I have a job that is enjoyable and stimulating

\section{REFERENCES}

[1] The Economic Planning Unit. (2010). Tenth Malaysian plan. [Online.] Available: http://www.pmo.gov.my/dokumenattached/RMK/RMK10_Eds.pdf

[2] H. Atan. (2007). English proficiency still low at local varsities [Online]. Available: http://goo.gl/DXfJa

[3] H. A. R. Muaizzah, "A study of English language teacher motivation in secondary schools in the district of Maran, Pahang," Master thesis, Universiti Malaysia Sarawak, Kota Samarahan, 1998.

[4] S. S. C. Mat and M. M. Yunus, "Attitudes and motivation towards learning English among felda school students," Australian Journal of Basic \& Applied Sciences, vol. 8, no. 5, 2014.

[5] B. S. Dweik and N. W. Awajan, "Factors that enhance English language teachers' motivation in Jordanian secondary schools," English Linguistics Research, vol. 2, no. 1, pp. 33-42, 2013.

[6] T. A. Judge and J. E. Bono, "Relationship of core self-evaluations traits - self-esteem, generalized self-efficacy, locus of control, and emotional stability — with job satisfaction and job performance: A meta-analysis," Journal of Applied Psychology, vol. 86, no. 1, p. 80, 2001.

[7] M. Praver and W. Oga-Baldwin, "What motivates language teachers: Investigating work satisfaction and second language pedagogy," Polyglossia, vol. 14, pp. 1-8, 2008.

[8] R. McQueen and C. Knussen, Research Methods for Social Science: A Practical Introduction, Edinburgh Gate: Pearson Education, 2002.

[9] H. Arksey and P. Knight, Interviewing for Social Scientists, London: Sage Publication, 1999.

[10] H.-Y. Yau, "Language teacher motivation: A study of teachers of English as a second language (Esl) in New Zealand language schools," Master thesis, School of Languages and Social Sciences, Auckland University of Technology, Auckland, New Zealand, 2010.

[11] E. Ushioda, "Motivation as a socially mediated process," Learner Autonomy in the Foreign Language Classroom: Teacher, Learner, Curriculum and Assessment, vol. 90-102, Dublin: Authentik, 2003. 


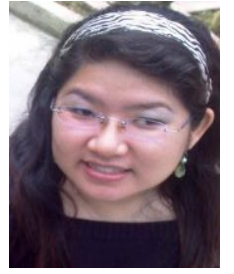

Chiew Fen Ng is a postgraduate student at Universiti Putra Malaysia (UPM). She is currently pursuing her master's degree of applied linguistics at the Faculty of Modern Language and Communication. She also holds a bachelor's degree in computer science from Coventry University. Prior to the pursuit of her postgraduate studies, she served as an educator at Erican Language Centre and Cosmotots for a few years. She has also worked at National Semiconductor as a production executive for a number of years before deciding to venture into the field of education. Her research interests include sociolinguistics, pragmatics, discourse analysis and English for specific purposes. and the other authors may include biographies at the end of regular papers.

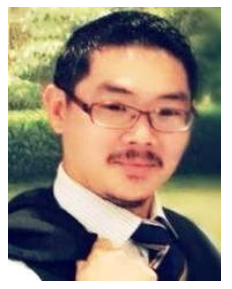

Poh Kiat Ng is a senior lecturer from the Faculty of Engineering and Technology, Multimedia University, Malaysia. He is also a PhD candidate at the Technical University of Malaysia (UTeM). Prior to being an academician, he has worked as a manufacturing engineer in Infineon Technologies and as a process engineer in National Semiconductor. His research interests include ergonomics, biomechanics, knowledge management, total quality management, manufacturing management, engineering education, concurrent engineering, teaching strategies and learning strategies. 